\title{
Managing Intellectual Capital in Knowledge Economy
}

\author{
Eunika Mercier-Laurent \\ University Jean Moulin \\ Lyon 6 cours Albert Thomas 69008 Lyon, France \\ Email: eunika.mercier-laurent@univ-lyon3.fr
}

\begin{abstract}
The Strategic Knowledge Management considers Intellectual Capital as roots of all organizations activities. The success of organizations strongly depends on the way they manage all facets of knowledge and skills. Artificial Intelligence brought some methods and techniques for handling intellectual assets of companies, expertise management, knowledge transfer and training. This paper presents a short overview of experiences and research in the field of intellectual capital management and gives some perspective for future.
\end{abstract}

\section{INTRODUCTION}

$\mathrm{S}$ INCE over two decades the interest for managing intangible assets, including intellectual capital has been grown. However the roots of intellectual capital go far back in the history. In XX century the term of human capital has been probably re-introduced by the economist Theodore Schultz in 1961 [1]. He considers that the investment in human capital is crucial for the economic development and the education has a key contribution. Latter the term of "intellectual capital" have been introduces to cover larger field including patents and documents. Among training professionals, Karl Erik Sveiby [2] defined an Intangible Assets Monitor to drive the management of human capital.

Probably the first effort in applying the artificial intelligence techniques to managing skills in a given situation was the application developed for French police [3]. These principles were used in larger system for managing security of the Winter Olympic Games [4]. The techniques such as casebased reasoning can be useful for matching demand and offer (looking for a job or a skill). Organizations such as OECD [5] have been involved in defining a general methodology for measuring intangible investment since 1989 .

The globalization changed the game of economic development. Intellectual capital has become an important asset and its assessment and management has turned to a priority for the Knowledge Economy. The intellectual capital is among the hot topics of conversations, conferences, magazines, scientific journals, books and reports. However com- panies and organizations are still measuring their success in term of financial capital and ROI (return on investment).

This paper presents key references related to the evolution of human capital, gives some elements of economic and environmental context and mentions current efforts in measuring of intellectual capital. It is followed by a presentation of a method and tools to manage this wealth differently and to stimulate a reflection on the role of this capital in the Knowledge Economy and in the Innovation Ecosystems.

\section{STATE OF THE ART}

The issue of intellectual capital is complex. It involves various fields such as management, psychology, economy, sociology, health, intellectual property rights and recently sustainable development. Intellectual capital forms the basis of the successful development of companies and countries. Such a development requires the right way of managing the intangible wealth in connection with tangible ones.

Numerous publications provide a multidisciplinary view of the subject. According to Theodore Schultz [1], in charge of economic development, the education is the most important in managing of "human capital". Another economist Gary Becker [6] considers education, training, and health as the major investments in human capital.

Leif Edvinsson [7] points out the role of intellectual capital in the modern economy.

OECD [8] highlights the role of human capital in the wellbeing of nations.

According to Dixon [9], training, capacity building and learning are key enabling factors for "sustainability" seen as long term ability of individuals and organizations to produce innovations as a reaction and adaptation to changes in external conditions. It is the link between opportunities, projects, addressing the real needs, and building capacity or empowerment that ensures useful learning, innovation and an economically efficient process. Training supports the 
development of all phases of the project lifecycle (situation analysis, forecasting, planning, implementation and evaluation /measurement of impacts). Trained persons develop skills and produce methods, information and knowledge required for the success of the project. Training, combined with the development and implementation of projects on the local level, allows: i) increasing and mobilizing human and social capital ii) developing new activities and iii) creating interactions leading to collective dynamics to the invention of new rules and standards (institutional capital) needed to integrate new activities in formal economy.

Folke et al, [10] propose to develop an "adaptive capacity". The concept has been used in biology and in the context of climate change, but applies to a much broader range of issues. Adaptive capacity developed in poor countries is extremely important to be successful in XXI century. Persons able to adapt and to solve problems using individual and collective knowledge, as well as solutions from the past that work for current challenge, is able to survive and even lead in global dynamics - Mercier-Laurent [11]. Viability theory of Aubin [12] may be useful to control the balance of the ecosystems based on human capital as engine

According to Charles Savage [13] the $5^{\text {th }}$ generation of managerial methods has to consider knowledge as asset. This statement has been enhanced by Debra Amidon [14] in The Innovation Strategy for the Knowledge Economy. To know is the opposite of to have attitude cultivated in today world and focus exclusively on quick business. From education point of view the most important is to learn how and what to learn.

These few references cover a large spectrum on human and intellectual capital themselves and the roles they play in economic development and the wellbeing of the nations

\section{ECONOMIC AND ENVIRONMENTAL CONTEXT}

The current economic situation in the developed countries and intensive industrialization in Asia generate new problems and needs - among them we can mention the industrial decline and unemployment in developed countries, exodus from regions to towns and the emergency of planet protection. In search of the cheapest work cost China has become the world factory. Goods travel all around the globe, generating pollution. Asian people are also studying abroad to increase their intellectual capital and sometimes bring it back to their respective countries.

In Europe the emphasis is on education and innovation is seen as a magic wand to renew industry. Despite the recommendations of the Lisbon treaty, the impact of education and innovation is still not measures in term of job creation and economic development of the regions and countries.

The intensive industrialization from the beginning of $20^{\text {th }}$ century did not taken into account the impact of these activities - Lenkowa [15], Eckholm [16] on the planet. The recent alerts points out the extreme emergency - ArthusBertrand [17]. The Sustainable Development and Corporate Social responsibility movements focus on the use of local resources. While companies are concerned about carbon and recently about water footprint, less about raw materials, they seem not concern by biodiversity. In reality they still do not manage the human capital; the local skills and know-how are not taken into consideration, because of the lack of holistic approach. By consequence skilled people are travelling. Despite ubiquitous information and communication technology these movements remain significant even increase.

The appropriate management of human capital and the education of knowledge cultivators will certainly bring a contribution to planet ecosystems protection.

This challenge is among the most important of the 21 century. It is vital to understand, know and manage intellectual capital in connection with others tangible and intangible assets of companies and other organizations, of cities, regions and countries using a combination of holistic and system approaches - Mercier-Laurent [11].

\section{MANAGING HUMAN CAPITAL}

While some thinkers state that the human capital is the most important asset, only few are measuring and managing it. The most important barrier in managing intellectual capital is the ignorance. Another one is a way of thinking.

The are a plethora of various data bases, even big data, but still built using traditional information processing methods, as a very limited number codes for professions ${ }^{1}$, taking into account only traditional ones. Pole d'Emploi (national center for employment) and other public initiatives in France are supposed to help people in finding jobs, but their efficiency is very low, because they are not using the right methods and tools.

With the quick progress of technology and artificial intelligence, computers are able to process natural language instead of codes. This open programming approach allows including in real time new professions that appear every day.

There is also a lot of valuable paper and electronic reports about intellectual capital containing key information and complex charts, very useful to know the current status, but they are static.

\footnotetext{
${ }^{1}$ for example all information services are coded $721 \mathrm{Z}$
} 
For someone looking for a local know-how, it is not easy to find quickly a right person. Some social networks such as Viadeo in France or LinkedIn are trying to connect talents and those who are looking for. Google is certainly among the most efficient search engines, but its business model introduces an important "noise" (and intellectual pollution) due to the advertisement system management.

\section{Know what we have}

A concept of "knowledge trees" have been introduced by Michel Autier and Pierre Levy [18] and implemented in tools as Ginko (Trivium) and Selva (Ligamen), offering graphic representations of individual and collective skills as a tree.

The Figure 1 illustrates the skills of 10 people: the trunk represents common knowledge, branches the specialties, and leaves the unique skills. Such an image provides information on everyone's ability and helps to decide if the unique skills represented by the leaves are strategic.

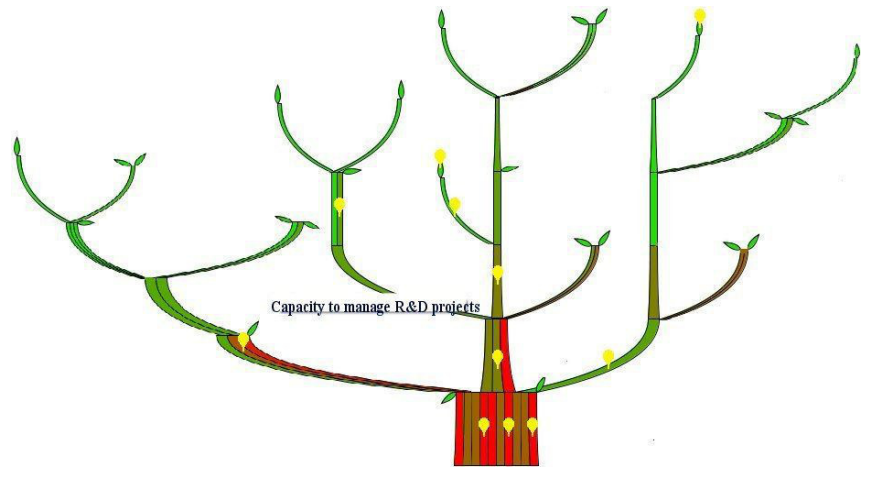

Figure 1 "Knowledge tree" created using the Ligamen software (http://www.ligamen.fr)

The part to the far right of the trunk, as well as the triple branch, indicate the position of a person in a group. Such visualization facilitates the identification of skills and helps to detect the lacks in relation to a required profile, which can be filled by training. Thus, we can build the competency tree of a company or a region and reason backwards: what projects can we achieve with such intellectual capital? We then need to search for the skills in a neighboring region or "rent" them to a partner.

In the international context and within a networked enterprise, it would be better to manage skills with a holistic perspective - on regional, national and international levels. This intangible wealth can grow through continuous learning from interaction with the environment, according to corporate strategy.

The training department is in charge of making this capital grow. It is involved for now, because in the global
Knowledge Management approach all knowledge cultivators are constantly learning.

The training department could be a guardian for the transmission and preservation of the essential knowledge and know-how of retiring, especially when this is the knowledge of a long-life and is a strategic product for the company. Collaboration between several professionals facilitates the skills management.

\section{Find the right profile}

When we know what we have and what we are looking for, one of artificial intelligence techniques - case-based reasoning [19] could be very helpful. The built-in analogy engine works by matching demand (I am looking for) and offer (base of existing skills and know-how) to find instantaneously the profile we want, if such a profile is registered. If not, a set of similar profiles that could be adapted to the expected ones by training is proposed to the user. We can imagine a World Knowledge Base including Talent Bank equipped with such an engine.

The various methods of measuring the value of human capital of a company, city, region or country provide the information on what we have. But it is certainly most useful to know what can be done with for future development, what new activities and companies may be created. This purpose is illustrated in Figure 2.

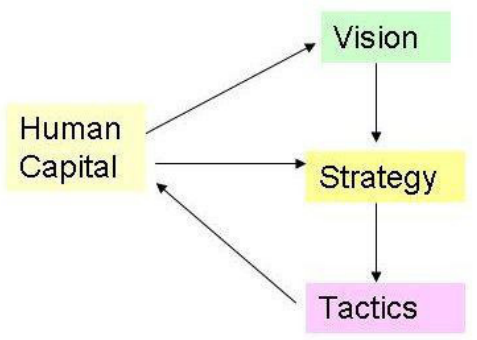

Figure 2 Human capital dynamics

A company/city/region need to elaborate a clear vision for the future. At this point the skilled persons able to envision it are needed. This vision will be "translated" into corporate strategy and a tactics (actions to achieve the strategic goals). The intellectual capital of professional working on accomplishing various tasks grown and the new knowledge and capacity should be taken into account at strategic level. It may also influence the vision.

\section{V.SKILLS FOR THE FUTURE}

Today educational system produces the traditional professionals. Many of them face the difficulty in finding job in their region or country. The most audacious travel for job; change country, language and continent. They have to adapt to new conditions and to new culture. 
As mentioned before, our future depends on our capacity to adapt, to detect opportunities and to gather necessary skills and knowledge and to transform them into economic values, in balance with ecosystems. It also depends on the rapidity of our decision making, on our risk taking ability in a dynamic environment, and on our ability to use the computer, regardless of its form, as an intelligent assistant. The latter facilitates an innovation without boundaries between fields (out of the box thinking).

Facing the affluence of information and solicitations, a new skill is required - the innovation know-how. This is the art of finding and exploiting strategic information and of gathering momentum and developing the knowledge and skills essential to the success of this enterprise, which is innovation in its entirety.

These skills are numerous - from the management of ideas and people to the implementation and commercialization.

Although Europe has a long innovation tradition since the industrial era, globalization has changed the odds. The factors such as the slowing down, the obsolescence of some sectors and the emergence of others, as well as the relocation of activities, influence active knowledge and skills. The lack of interest expressed by youths in scientific studies will lead to a shortage of engineers. Some skills are disappearing with retirements, which are sometimes accelerated by the economic crisis. Knowledge capitalization approaches are saving a part of the strategic and "sensible" skills, but these initiatives are quite rare and are often initialized too late.

The European document Putting Knowledge into Practice (European Commission 2004) specifies that the lack of skills, notably in the fields of sciences, engineering and ICT, is a challenge for European education. Another publication, Innovate for a Competitive Europe (European Commission 2004) advises companies to learn how to transform the absorbed knowledge into action. Such an innovation dynamics combines the knowledge and skills in value creation. Kolding et al 2009 describe the skills we need to acquire to face the post crisis era in Europe. The authors are convinced that the ICT skills are the most important, but they did not mention what approach to ICT and to computer programming should be used.

Companies training departments need to focus on the transformation of today capacities good for industrial economy to those that are essential for Knowledge Economy. The progress can be measured using for example the trees of knowledge software, or other that may help.

\section{CONCLUSION}

To build a sustainable future we need more than data base, reports and dashboards, we need a disruptive innovation in the way we build, evolve, maintain and manage the human capital.

We need a new educational system, having the ambitious task of changing mentalities and values, to educate a culture of knowledge cultivators and to increase imagination and creativity. Main challenge of education is to teach how to learn, the curiosity, adaptability, capacity of solving problem with limited resources and to undertake and succeed collectively. This education is based on exchanges, listening and respecting the others opinions; an education for all, to learn from nature, from the past and from differences, in which technology and means of communication have a significant role to play.

We need to use the power and "intelligence" of computers and other connected devices. When programmed using "knowledge thinking", they can bring a significant helps in storing, updating, displaying, matching and finding the relevant elements of human capital.

We need to create synergy between educational programs and local needs as well as a dynamics vision for the future.

New metrics could be: boldness, imagination, associations (links making), and capacity to find and use the appropriate knowledge, mental flexibility, knowledge and ecosystem thinking, capacity to transform ideas in value and to envision the future. The estimation of 5D impacts of resulting activities - economic, technologic, cultural, social and environmental, could be added to measure the progress. Such a wise management of intellectual capital, supported by electronic "intelligent" assistants and appropriate measure of progress is essential for the development of companies, regions and countries.

\section{REFERENCES}

[1] T. Schultz Investment in Human Capital, The American Economic Review, 1961, Vol. 51, No 1, pp. 1-17.

[2] K. E. Sveiby The New Organisational Wealth - Managing and measuring Knowledge-Based Assets. Berrett-Koehler, San Francisco, 1997

[3] N. Geraud, P. Rincel., N. Vandois ARAMIS-GM Un système intelligent d'aide à la décision pour la gestion des effectifs de Gendarmerie Mobile, Systèmes Experts et leurs applications, Avignon 1990.

[4] V. Lacroix, Lacroix, Lieutenant Colonel Daville : RAMSES I in système d'aide à la décision pour la sécurité des Jeux Olympiques, Systèmes Experts et leurs applications, Avignon 1991

[5] OCDE 1996, Measuring What People Know. Human Capital Accounting for the Knowledge Economy

[6] G. S. Becker Human Capital: A Theoretical and Empirical Analysis, with Special Reference to Education. Chicago, University of Chicago Press. ISBN 978-0-226-04120-9, 1964

[7] L. Edvinsson, M. S. Malone, Intellectual Capital: Realizing your Company's True Value by Finding Its Hidden Roots. New York: Harper Business, 1997

[8] OCDE, The Well-being of Nations. The Role of Human and Social Capital. Education and Skills, 2011, http://www.oecd.org/site/worldforum/33703702.pdf

[9] P. Dixon, J. Gorecki, Sustainagility. How Smart Innovation and Agile Companies will Help Protect our Future. Kogan Page Publishers, 2010, London. 232p, 20 
[10] F. Berkes, J. Colding, C. Folke (eds). Navigating Social-Ecological Systems, Cambridge University Press, 2003, UK, pp. 352-387

[11] E. Mercier-Laurent, Innovation Ecosystems, Wiley, 2011, 248p. ISBN 978-1-84821-352-8

[12] J. P. Aubin, Viability Theory, Birkhauser Boston, 1991

[13] C. Savage, 5th Generation Management: Integrating Enterprises through Human Networking, The Digital Press, Bedford, 1990

[14] D. Amidon, The Innovation Strategy for the Knowledge Economy, Heineman Butterworth, Boston, 1997

[15] A. Lenkowa, Oskalpowana ziemia, Omega, Wiedza Powszechna, Warsaw, Poland, 1969

[16] E. P. Eckholm, Losing Ground. Environmental Stress and World Food Prospects, W.W. Norton and Company, New York, 1976

[17] Y. Arthus-Bertrand, Home, 2009 https://www.youtube.com/watch? $\mathrm{v}=\mathrm{jqx} \mathrm{ENMKaeCU}$
[18] M. Autier, P. Lévy Pierre, Les arbres de connaissances, 1992, La Découverte, Paris

[19] J. Kolodner, Kolodner Jeannet, Case-Based Reasoning, Morgan Kaufman, 1993, 668p, ISBN 978-1558602373

[20] European Commission, Implementing the partnership for growth and jobs: Making Europe a pole of excellence on corporate social responsibility, 2006

[21] European Commission, 2004, Innovate for a Competitive Europe. A New Action Plan for Innovation, 2 April 2004

[22] M. Kolding, M. Ahorlu, C. Robinson C.., Post crisis: e-skills are needed to drive Europe's innovation society, IDC EMEA,2009, London, United Kingdom

[23] A. M Youriev History of human capital, 2014, http://www.yuriev. spb.ru/polit-chelovek/human-capital-resource 